\title{
TTR
}

Traduction, terminologie, rédaction

\section{Sergey Tyulenev. Translation and Society. London and New York, Routledge, 2014, 218 p.}

\section{Esmaeil Kalantari}

Volume 28, numéro 1-2, 1er semestre-2e semestre 2015

URI : https://id.erudit.org/iderudit/1041660ar

DOI : https://doi.org/10.7202/1041660ar

Aller au sommaire du numéro

\section{Éditeur(s)}

Association canadienne de traductologie

ISSN

0835-8443 (imprimé)

1708-2188 (numérique)

Découvrir la revue

Citer ce compte rendu

Kalantari, E. (2015). Compte rendu de [Sergey Tyulenev. Translation and

Society. London and New York, Routledge, 2014, 218 p.] TTR, 28(1-2), 262-266.

https://doi.org/10.7202/1041660ar d'utilisation que vous pouvez consulter en ligne.

https://apropos.erudit.org/fr/usagers/politique-dutilisation/ 
de dépassement: sa traduction vers l'anglais, la langue d'assimilation de la communauté juive, se matérialise dans le travail de poètes comme Irving Layton et A. M. Klein, les deux premiers poètes juifs montréalais à écrire directement en anglais. Ce qui relie, comme dans un élan de survivance, l'écriture yiddish de Montréal et son pendant bien vivant francophone aujourd'hui s'incarne dans le travail de Pierre Anctil, traducteur des grandes œuvres yiddish de la ville vers le français. Le va-et-vient traductionnel à Montréal ne se limite pas à une mobilité uni- ou bidirectionnelle. Au contraire, l'enrichissement du patrimoine se fait au gré des influences culturelles et littéraires, qui ne se contentent pas de suivre une chronologie linéaire.

Villes en traduction est bien plus qu'une recherche universitaire: l'ouvrage bénéficie d'un œil sensible à la poésie de la traduction et de son déplacement socioculturel continu, propre à chaque ville, sur l'axe du temps comme sur celui de l'espace. Simon démontre que ce mouvement prend racine chez les écrivains-traducteurs, dont les œuvres sont le reflet de leur ville. En terminant, il faut mentionner la performance magistrale du traducteur Pierrot Lambert, qui a su faire ressortir avec brio en français tout le travail de terrain fait par l'auteure.

Marie Leconte Université de MontréAL

\section{Sergey Tyulenev. Translation and Society. London and New York, Routledge, 2014, 218 p.}

The sociology of translation is one of the significant recent developments in the field of Translation and Interpreting Studies (TIS). There are a number of publications (e.g. Wolf and Fukari, 2007) that draw on sociological theories (e.g. Bourdieu, 1989) to study translators and translation. In line with this interest, Translation and Society investigates sociological theories and their pertinence to research in TIS. The author of the volume, Sergey Tyulenev from Durham University, is primarily interested in researching translation as a social activity and has experience teaching the sociology of translation. An earlier publication, Applying Lubmann to Translation Studies: Translation in Society (Tyulenev, 2012), develops a way to apply social systems theory (SST) to translation. Tyulenev's research and teaching background 
puts him in a good position to develop, in this volume, a fullscale sociological approach to the study of translation. The main objectives of the book are to clarify the aims of studying translation from a sociological viewpoint, to strengthen the foundation of sociologically-informed translation research, and to open up new avenues to explore the sociology of translation. The book successfully meets these objectives, because Tyulenev most appropriately approaches not only translation but also translators sociologically.

The first chapter explains why translation should be studied sociologically. It is argued that translation is a social activity because it mediates between peoples. In addition, translators are socialized individuals, who take their worldviews from the society to which they belong. Socialization influences the translators' decisions and can be detected in their translation products. One example is the Greek translation of the Hebrew Bible, in which details are believed to have been added by the translators unintentionally. In fact, in the course of interpreting some ideologically problematic passages, the translators' socialization (i.e. the translators' religious beliefs) influenced translational decisions unconsciously. Accordingly, Tyulenev concludes that sociology is a science which allows for theorizing translation as a social phenomenon.

The second chapter of the book is devoted to culture, as a sociological category used in many social sciences including TIS. Culture comprises values and conventions, and these values and conventions are transmitted to individuals through society. The role of translation in the social transmission of culture is to mediate between cultures or subcultures (i.e. communities with their own cultures within a national culture), as well as between a given culture and its subcultures. The mediation of translation can be either intercultural or intracultural. To explain the intercultural role of translation, the author refers to the westernization of Russia. Translation facilitated the modernization of Russian society by introducing Western culture to Russian culture. As for the intracultural role of translation, a translator may observe a subcultural social group and translate his observations in a way that the target audience, who might be another subculture or the national culture, can understand.

The discussions in the third chapter revolve around the question of socialization. Tyulenev draws on some theories of 
socialization that are applicable to the study of translation. For instance, he explains Freud's theory in which the id, ego, and super-ego are considered to be three levels of human personality. The id represents selfish desires, the super-ego determines an individual's behavior according to cultural norms, and the ego strives to strike a balance between the id and super-ego through sublimation. This theory is relevant to the study of translation since a translator (or, rather, the translator's id) may have, for instance, a high level of creativity that is limited by his super-ego. This creativity would be then sublimated by the translator's ego implementing unconventional translation strategies. Applying Freud's theory to the study of translation allows for considering the forces that determine translator's behavior, but that have not yet been theorized.

The fourth chapter focuses on translators as professionals. Some requirements (e.g. having formal qualifications) must be met for members of an occupational group to be considered professionals. In the case of the translation profession, requirements for both translators and the translation products exist. On the one hand, translators need to have formal qualifications to be able to work. On the other, a particular translation may be considered valid by an institution, only if it has been approved by a certified translator. Furthermore, Tyulenev describes professionalism as being "characterized by the importance assigned to the formalization of governance of the practice" (p. 76). Accordingly, he argues that, as a professional practice, translation is governed by social and professional norms, and, thus, translators do not have an absolute freedom of choice.

Chapter five addresses the issue of conducting research in the social sciences in general and in TIS in particular. In this chapter, the difference between methodology and method is clarified. Methodology (e.g. (post) structuralist) is the theoretical foundation of research methods, whereas method is a practical research technique. Also, Tyulenev explains some of the most important quantitative (e.g. statistical analysis) and qualitative (e.g. discourse analysis) methods that are used in social sciences research and describes how they are applicable to the study of translation. For example, statistical analysis is useful to show the dynamics of translation, whereas discourse analysis is applied to the study of how language is used in translation. The last section 
of the chapter is particularly interesting, for it argues that doing research in the social sciences based on one method exclusively is not feasible due to the complexity of social phenomena.

The sixth chapter starts out by clarifying the differences between a model, a perspective, and a theory. The chapter's main objective is to introduce some social sciences models and perspectives that are relevant to research in TIS. One of the sociological models discussed is "the organismic or structuralfunctionalist model of society" (p. 110). This model, also called the "equilibrium model of society" (ibid.), studies the parts that constitute society and how they are related to each other and to society as a whole, in order to better understand how society retains its order. Tyulenev argues that translation is related to the equilibrium model as it, interlingually and intralingually, bridges the gap between groups speaking different or similar languages and, in this way, attempts to maintain or restore social order.

Chapter seven focuses on the unit of analysis in the sociological study of translation. The author draws on some (macrosociological) functionalist theories (e.g. Luhmann's SST) which are pertinent to TIS. In fact, the functionalist approach to the study of translation allows for considering the "translation's element" (p. 134), that is the totality of translational relations, as the unit of analysis in studying translation sociologically. This unit is called the "translation communication event" (TCE) (p.134). The TCE has a unique structure: two communication events are joined by mediation. Tyulenev emphasizes that, in this structure, mediation highlights the fact that the TCE mainly fulfils a social function and, therefore, translation can be conceptualized as a social activity.

Chapter eight introduces and links some microsociological theories (e.g. social phenomenology) to the study of translation, with reference to the notion of "lifeworld" in phenomenology (p. 155). This concept brings forth the idea that the world is defined by how people see it, and not by what it really is. Interestingly, the idea of "lifeworld" (ibid.) is valid when applied to the sociological study of translation. In order to bridge the gap between two cultures, translation products often have (almost) the same vision of reality as the source texts. The author believes that translators try to make the lifeworld of the source text and that of the target text compatible. 
In the last chapter, some theories that strike a balance between macro- and microsociological theories are investigated. One example of such theories is "constructivist structuralism" (p. 170). Tyulenev describes the key concepts of this theory in order to show how it relates to TIS. For instance, the term "conatus" means "a mixture of inherent unconscious or semi-conscious features with seemingly independent projects that one formulates for her/himself" (p. 180). Translated works feature different types of conatus. For example, there may be a clash between a translator's unconscious or semi-conscious closeness to the conatus of home interests (e.g. national interests) and the conatus of faithfulness to the values of the source text.

The book comes to its end with a short conclusion in which the author emphasizes that in current sociological research the macro- and microsociological approaches are combined. That is because employing merely one of these approaches makes it impossible to investigate the interaction between, for example, the mind (individual) and structure (society), as key themes in modern sociology that are applicable to TIS.

This volume makes an important contribution to the field of Translation and Interpreting Studies by successfully explaining why sociology is a science that should be taken into account in the study of translation. Moreover, the formulation of numerous research questions throughout the book makes it a rich source of inspiration for post-graduate students, professors, and researchers who are interested in studying translation sociologically. Overall, the book is a welcome addition to the existing literature on the sociological study of translation.

\section{References}

Bourdieu, Pierre (1989). "Social Space and Symbolic Power." Sociological theory, 7, 1, pp. 14-25.

Tyulenev, Sergey (2012). Applying Lubmann to Translation Studies: Translation in Society. New York and London, Routledge.

Wolf, Michaela and Alexandra Fukari, eds. (2007). Constructing a Sociology of Translation. Amsterdam/Philadelphia, John Benjamins.

Esmaeil Kalantari Université DE Montréal 